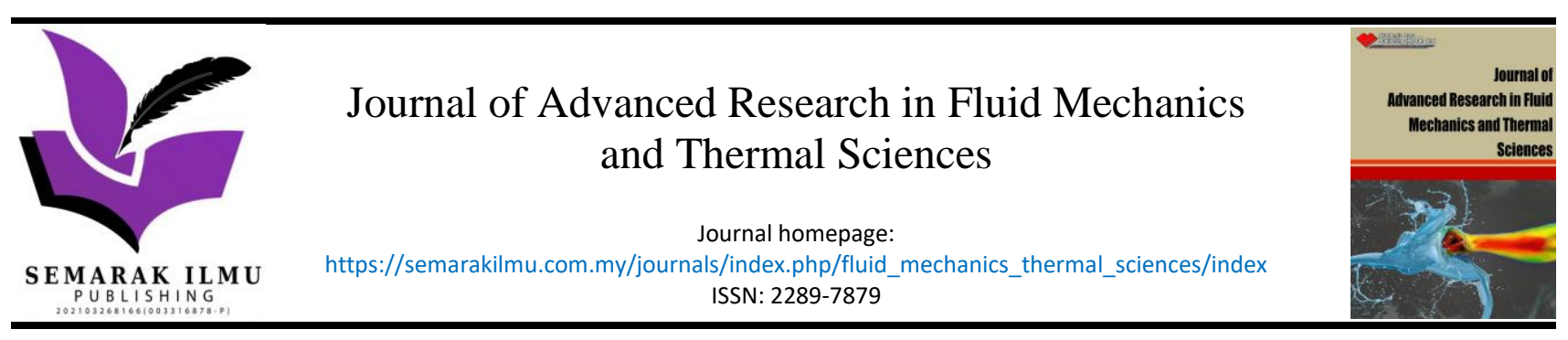

\title{
Polyethylene Terephthalate Waste Utilisation for Production of Low Thermal Conductivity Cement Sand Bricks
}

\author{
Rafikullah Deraman ${ }^{1,}{ }^{*}$, Mohd Nasrun Mohd Nawi ${ }^{2}$, Mohd Norazam Yasin ${ }^{1}$, Mohd Hanif Ismail ${ }^{3}$, \\ Rami Salah Mohd Osman Mohd Ahmed ${ }^{3}$ \\ 1 Project and Facilities Management (ProFaci), Faculty of Civil Engineering and Built Environment, Universiti Tun Hussein Onn Malaysia, 86400, \\ Batu Pahat, Malaysia \\ 2 Disaster Management Institute (DMI), School of Technology Management and Logistics, Universiti Utara Malaysia, 06010 Sintok, Kedah, Malaysia \\ 3 Department of Civil Engineering, Faculty of Civil Engineering and Built Environment, Universiti Tun Hussein Onn Malaysia, 86400, Batu Pahat, \\ Malaysia
}

\section{ARTICLE INFO}

\section{Article history:}

Received 5 July 2021

Received in revised form 15 October 2021

Accepted 20 October 2021

Available online 13 November 2021

\section{Keywords:}

PET plastic bottle; sand replacement; thermal conductivity; insulation; cement sand brick

\section{ABSTRACT}

There is a tremendous increase in plastic waste that negatively impacts the environment due to various industrial activities. Furthermore, plastic waste has non-biodegradable properties that make it hard to reduce its accumulation around the globe. Hence, this study aims to investigate the possibility of incorporating Polyethylene terephthalate (PET) waste as a partial replacement material of sand to improve the thermal insulation properties of cement sand brick by looking at findings of low thermal conductivity value. The study uses a PET plastic bottle that has been cut into small flakes and grind using a granulator machine to produce PET waste granules whose size is not more than $5 \mathrm{~mm}$, similar to the sand size. This waste was added to other raw materials, i.e., cement and sand. The percentages of PET waste vary from $2.5 \%, 5 \%$, and $7.5 \%$ by weight. This study produced two types of samples, i.e., control brick and PET waste cement sand brick. All samples undergo laboratory works involving geotechnical gradation, physical, mechanical, and thermal conductivity testing. Based on the results obtained, the optimum proportion of PET waste replacement in cement sand bricks making is $5 \%$ by its having the lowest thermal conductivity value of $0.581 \mathrm{~W} / \mathrm{mK}$ and meeting the standard requirements of 3.90 $\mathrm{MPa}>3.45 \mathrm{MPa}$ (ASTM C129-11 for compressive strength), and $2,146 \mathrm{~kg} / \mathrm{m}^{3}>2,000 \mathrm{~kg} / \mathrm{m}^{3}$ (ASTM C129-11 for normal weight non-loadbearing brick). Thus, PET plastic bottle waste can be a potential partial sand replacement material in cement sand bricks. Its potential to enhance the thermal conductivity of existing cement sand brick reduces sand consumption, solves plastic waste problems, and promotes a better environmentally-friendly construction industry.

\section{Introduction}

Plastic produces the third-highest waste source globally, with the total volume of plastic waste growing relatively with increases in the global population and per capita consumption. The world generates 2.01 billion tons of solid urban waste per year, at least 33\% of which are not managed in an

\footnotetext{
* Corresponding author.

E-mail address: rafikullah@uthm.edu.my
}

https://doi.org/10.37934/arfmts.88.3.117136 
environmentally safe manner, in addition to a growth forecast of 3.40 billion tons by 2050 [1]. Malaysia, for example, is one of the largest countries in Asia that producers plastics, with over 1,550 manufacturers, employing 99,100 workers [2]. The increasing consumption of plastic in various industries and sectors has led to the generation of a high volume of plastic wastes in the world [3]. Plastic waste exerts a strong influence on the environment because it is a non-biodegradable material that can carry serious environmental threats, even more so through a modern way of life that uses many materials from plastic. Geyer et al., [4] reported that the global primary plastics waste generation increased from 1950 to 2015 in the industrial sector. Plastic wastes constituted $19 \%$ of the total waste generated in Malaysia [5]. Of this waste, $74 \%$ comprised single-use plastic films, $17 \%$ rigid plastics, and $9 \%$ foam plastics. Malaysia's percentage of plastic solid waste in Asia is second behind the Philippines [6], [7].

It has been reported that only $8.4 \%$ of the total plastic waste generated was recycled, while $75.8 \%$ was accumulated in landfills and the environment [8]. Many of the waste generated, especially from PET bottles, have resulted in water drains and eventually into the ocean. In the ocean, plastic continually breaks apart and gets smaller, ingested by marine species and other organisms. By 2050, it is estimated that there will be more plastic in the world's oceans than fish $[9,10]$. Macro, micro, and nano plastics have polluted the earth's soil, freshwater, and oceans [11], and such pollution kills wildlife, damages natural ecosystems, and contributes to climate change [12]. Studies show that the construction industry is one of the main sectors that have the potential to reuse solid waste as a potential raw material for several purposes, such as partial substitutions of raw materials for the production of building materials [13].

Diversely, the building sector has a major impact on the quality of the environment, as it consumes $40 \%$ of the total energy, $50 \%$ of the total extracted materials, and $36 \%$ of the total $\mathrm{CO}_{2}$ emissions globally [14]. This large amount of energy used and related emissions will increase due to the increasing supply and demand of housing, especially in developing countries. Thus, it is necessary to take steps for new construction projects that efficiently use energy, natural resources, and materials. A major portion of building energy is consumed to provide a comfortable and healthy environment for its occupant through heating, air-conditioning, and ventilation [15]. Therefore, new building construction provides the best opportunity for improvised building envelopes, which can help reduce building energy usage.

Moreover, selecting building materials for building envelopes is one of the methods to decrease the energy usage in the buildings. The strain on conventional energy can be reduced by utilising low embodied energy building materials and efficient structural design. The choice of materials also helps to maximise the comfort of the indoor environment. Using materials and components with small embodied energy or low thermal conductivity can enhance indoor comfort in buildings $[16,17]$. The utilisation of low thermal conductivity building materials is important to minimise the unwanted heat transfer between the outdoor and indoor environments to comfort the occupants. The material that has a lower thermal conductivity value is a good thermal insulator. Appropriate thermal insulation in building envelopes can significantly reduce the amount of electricity consumed for space heating and cooling and eventually reduce the degradation of energy quality and cause $\mathrm{CO}_{2}$ emissions [18]. In addition, low thermal conductivity brick becomes an alternative building material for green construction, which is processed by increasing air voids and including high thermal insulation materials into the brick.

As the intention of integrating sustainable development with the building sector, several attempts have been made to use natural or recycled materials having insulation properties in the construction of energy-efficient building envelopes [19]. Plastic wastes make an excellent choice as it decreases environmental pollution and also help save the energy used in recycling and production processes $[20,21]$. In addition, the properties of plastic, like its durability, chemical resistance, and low thermal conductivity, reinforce its popularity as a building material [22]. Among all the available plastic waste types, PET is one of the most widely used in building construction because of its high dielectric and insulating properties $[19,21,23]$. 
There are many types of plastic produced globally. Typically, plastic is divided into seven categories, and not every type can be recycled in Malaysia. These categories are Polyethylene terephthalate (PET/PETE), High-density polyethylene (HDPE), Polyvinyl Chloride (PVC), Low-Density Polyethylene (LDPE), Polypropylene (PP), Polystyrene (PS), and others [24]. The local recycling industry only concentrates on recycling three plastic categories out of seven due to being easily retrievable and holding high value. Generally, three types of plastic are capable of recycling, i.e., PET, HDPE, and LDPE. The world's PET production is for synthetic fabrics (more than 60\%), with bottle production contributing about $30 \%$ of global demand [25]. The PET which the focus of this study is finding in massive quantity from bottles. Plastic bottles waste is difficult to biodegrade [26]. Figure 1 shows the effects (both physical and chemical) of plastic waste, including PET, on physical health.

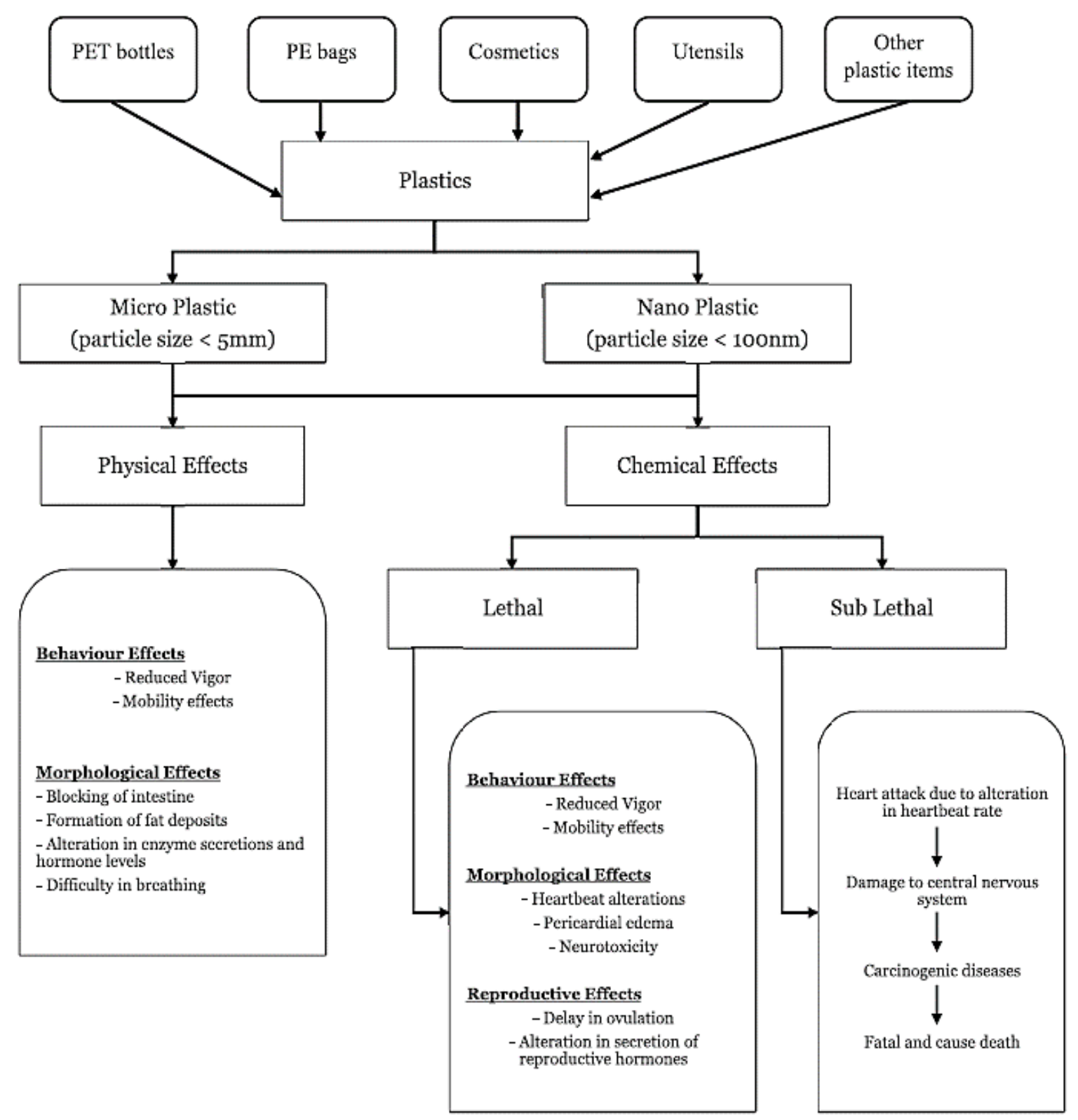

Fig. 1. Adverse impacts of plastic waste on physical health [27]

PET is a hard, stiff, strong, and dimensionally stable material. PET is widely employed as a raw material to manufacture products such as bottles for soft drinks and containers for food packaging and other consumer goods [28]. PET bottles had taken the place of glass bottles as storage for beverages due to 
being lightweight and the ease of handling and storage. Generally, the empty PET packaging is discarded by the consumer after use and becomes waste PET. Developing a practical application for recycled PET will encourage recycling, reducing the volume of plastics that can be seen in landfills or waterways and minimising the economic costs associated with plastic pollution. Numerous researchers started to explore the concept of incorporating recycled plastic into the cement-based mortar as either fine aggregate or fibre. Some have chosen to manufacture products out of recycled plastics such as bricks, panels, thermal walls, and thermal roofing. Marsiglio et al., [21] reported that a Philippines-based company known as Green Antz had produced Eco-bricks from a mix of cement and plastics.

Cement sand brick is one of the building materials used as an alternative for low-to-medium cost housing development and other commercial constructions in Malaysia. Cement sand brick is very easy to make, considering its low cost of production. This brick is mixed up with a combination of cement, sand, and water with a specified mix ratio such as $1: 6$, and the water-cement ratio is 0.6 . Cement used in the brick composition acts as a binder that sets, hardens, and adheres to other materials to bind them together. In detail, when cement mix with water, it forms a paste that sets and hardens through hydration reactions which, after hardening, retains its strength and stability. On the other hand, sand (fine aggregate) acts as a filler and occupies most of the volume in the brick mixed. The sand becomes cemented together and contributes to the structural properties of hardened brick. Sand usually helps in preventing brick mix shrinkage and also prevents cracking of brick mix during settling. Based on the standard requirement, the minimum permissible value of compressive strength non-load-bearing wall shall be not less than $3.45 \mathrm{~N} / \mathrm{mm}^{2}$ [29].

Numerous researches have shown that construction industries have contributed to the largest usage of natural resources and energy consumption that become the main issues of sustainability in Malaysia and worldwide $[30,31,32]$. For instance, the consumption of natural resources such as sand in brick production resulted in resource depletion, environmental degradation, and energy consumption $[33,34,35,36]$. Thus, many researchers have been researching green and sustainable materials to replace conventional building materials. For this research, using recycled PET for manufacturing plastic bricks is advantageous given the product longevity of bricks, which will keep plastic locked up for longer than many other applications, such as packaging [21]. The PET can partially replace fine aggregate (sand) at percentages less than ten (44). Studies by Akinyele and Toriola [37] of crushed plastic PET used in sandcrete brick can substitute fine aggregate in bricks at $0 \%, 5 \%, 10 \%, 15 \%$, and $20 \%$. However, the result revealed that crushed plastic PET could be used in sandcrete bricks if not more than $5 \%$ replacement.

Table 1 verifies the incorporation of PET in different types of construction materials that have been conducted by previous researchers. Limited studies utilised shredded PET waste of plastic water bottles into cement and sand brick mix that focuses on the low thermal conductivity materials production. This paper investigates the viability of using PET (shredded plastic water bottles) as one of the primary building materials in cement brick composition. The fine aggregate (sand) in a brick mix was partially replaced by plastic. The utilisation of PET waste of plastic bottles for the production of bricks is being studied for their low cost and lightweight properties and to improve the thermal insulation properties of existing cement sand brick by lowering its thermal conductivity value. Moreover, the use of PET bottles in cement sand brick composition also decreases the structure's dead load, which will help reduce the cost associated. Recycling the PET bottle as a primary material, and upcycling it into a profitable product, could reduce the number of plastics entering the land and aquatic ecosystems, which is vital. 


\section{Table 1}

Summary of previous works that incorporate PET in construction materials from the academic database

\begin{tabular}{l}
\hline Title \\
Development of recycled PET fibre and \\
its application as concrete-reinforcing \\
fibre \\
The effect of using polyethylene \\
terephthalate particles on physical and \\
strength-related properties of concrete; \\
a laboratory evaluation
\end{tabular}

Utilisation of plastic waste in concrete as a partial replacement of concrete fine aggregate

The mechanical properties of brick containing recycled concrete aggregate (RCA) and polyethylene terephthalate waste as sand replacement

$\begin{array}{ll}\text { Year } & \text { Type of M } \\ 2007 & \text { Concrete } \\ 2016 & \text { Concrete }\end{array}$

2016

2018

Cement Sand Brick

Concrete

Analysis of physical and mechanical properties of pressed concrete blocks without structural purposes with additions of recycled PET
2019 Concrete Block

2019 Concrete Block
Refs

PET fibre had good mixability, has reinforcing

ability and shown easy handling

- Adding PET to the concrete mixture decreased both fresh and dry densities of concrete.

- By using PET, the weight of produced concrete is reduced.

- An increase in PET ratio and curing age makes samples more deformable before failure.

- Using PET in concrete will significantly reduce environmental pollution.

- Compressive strength: Compressive strength of concrete has been found decreasing gradually with the increase of adding plastic (max. 6\%)

- Environmental: Using plastic in concrete will significantly reduce environmental pollution.

- Density: The density steadily decreased with the increase of RCA and PET content in the mixtures.

- Compressive strength: The reduction of strength is shown when the volume of PET increases. An only a certain amount of PET fibre increases the strength of brick samples.

- Water absorption: The water absorption increased with the replacement percentage of PET wastes for all mixtures.

- Dry mass: A decrease in the dry mass of the blocks as more PET was added to the mixture.

- Water absorption: Block with $15 \%$ recycled PET presented a reduction of $14.49 \%$ when compared to the absorption of the control block. The higher the replacement contents, the absorption increased. 
Study of the suitability of unfired clay bricks with polymeric HDPE \& PET wastes additives as a construction material

Effect of waste PET on the structural properties of burnt bricks
2020

Unfired Clay Bricks

2020

Burnt /Fired Brick
- Thermal conductivity: The increase in the recycled PET content in the mixture decreases the thermal conductivity of block samples. The addition of PET increases the number of voids in the mixture, increasing the porosity in the composite. The greater the porosity, the lower the thermal conductivity.

- Compressive strength: The strength dropped sharply as the recycled PET content increased.

- Porosity: An increase of porosity level when the additive's size and the percentage are increased.

- Bulk density: A decrease in the samples' bulk density increases the additives' size and percentage.

- Capillary water absorption coefficient: A close relationship between the water absorption coefficient and porosity level. The higher the additive percentage is, the more porous the brick sample is.

- Compressive strength: The compressive strength is varied with the percentage of the additive used. The decrease of the compressive strength as the additives' percentage increases. The less porous the brick structure is, the higher the recorded bulk density of the specimen is.

- Firing shrinkage: PET materials melted during firing because of their low melting point and thus deformed in shape. Bricks must have a linear firing shrinkage lower than $8 \%$ to retain good mechanical performance.

- Water absorption: The water absorption values decreased with increasing firing temperature and decreased with increasing amounts of 
waste plastic in the mixtures. The PET materials in the bricks were water repellant as they occupied void spaces meant for water in the brick matrix.

- Compressive strength: Compressive strength of clay bricks samples decreased with an increase in the proportions of PET.

- Density: The more the presence of PET in a sample, the lower the density. The low density in PET-filled bricks was because of the lightweight of the PET material.

- Flexural strength: The presence of PET in samples reduced both the bending and shear stresses generated in the bricks.

- Microstructural properties: Capillary voids are present in the samples that contain PET. The large macrocracks on the samples with PET were due to the very poor bonding between the mixes and led to the low strength of the bricks containing the PET particle.

Water absorption, strength and microscale properties of interlocking concrete blocks made with plastic fibre and ceramic aggregates
- Water absorption: The plastic fibre in the interlocking blocks gave the least water absorption over a longer period. Reduction in water absorption can be attributed to the plastic fibres holding the concrete matrix together and reducing the pore spaces within the block.

- Compressive strength: The compressive strength of the interlocking blocks increased as the percentage of plastic fibre increased. The increase in compressive strength with an increase in the percentage of plastic fibre added can be ascribed to the plastic fibres holding the concrete matrix together, thus increasing the impact resistance of the interlocking blocks to load. 
- Splitting tensile strength: The increase in split tensile strength with an increase in the percentage of plastic fibre can be attributed to the plastic fibres holding up the concrete matrix together and increasing the interlocking blocks' resistance to load.

Analysis of mechanical and durability properties of alkali-activated blocks using PET flakes and Fly-ash
2021

Concrete Block

- Density: The block's density was found to be decreasing with the increase in PET content.

- Compressive strength: The compressive strength of blocks decreases with an increase in the replacement of PET flakes.

- Flexural strength: The flexural strength of blocks followed a similar trend as compressive strength result.

- Water absorption: Increase in water absorption was observed by increased replacement by PET flakes.

\section{Methodology}

The raw materials used to produce bricks samples are Ordinary Portland Cement (OPC), river sand, and PET plastic bottle. The OPC was manufactured from the Tasek Cement and fulfilled the requirement in the MS 522 [47]. River sand with at least $98 \%$ passing the $5 \mathrm{~mm}$ sieve was used. The water used for mixing and curing was the portable water treated by the local utility company with the $\mathrm{pH}$ value of 6.5-7, which complies with MS 28 [48]. Meanwhile, PET waste was obtained from mineral water bottles collected from the surrounding area of Parit Raja.

The plastic bottle was cut manually into small flakes with approximately a length size of $30 \mathrm{~mm}$ before undergoing granulating process using a granulator machine. The size of FET waste was cut at the required length to ensure the PET surface is flat as possible since the granulator has a rotating blade that can only process any material with a flat surface. The machine can grind the PET waste into smaller sizes, which in this study, the size of sieved PET waste granules is less than $5 \mathrm{~mm}$, making it physically similar to the sizes of sand. Figure 2 shows the production process of PET granules. The materials and design mix proportion of sand cement brick per sample prepared in this study are given in Table 2. The ratio of 1:6 was used as the mix design ratio of sand cement brick, and the water-cement ratio is 0.6 . The selection of mix ratio for the actual design mix shown in Table 2 was based on the trial mix result. The calculation of design mix proportion was prepared based on the weight of the brick sample. 


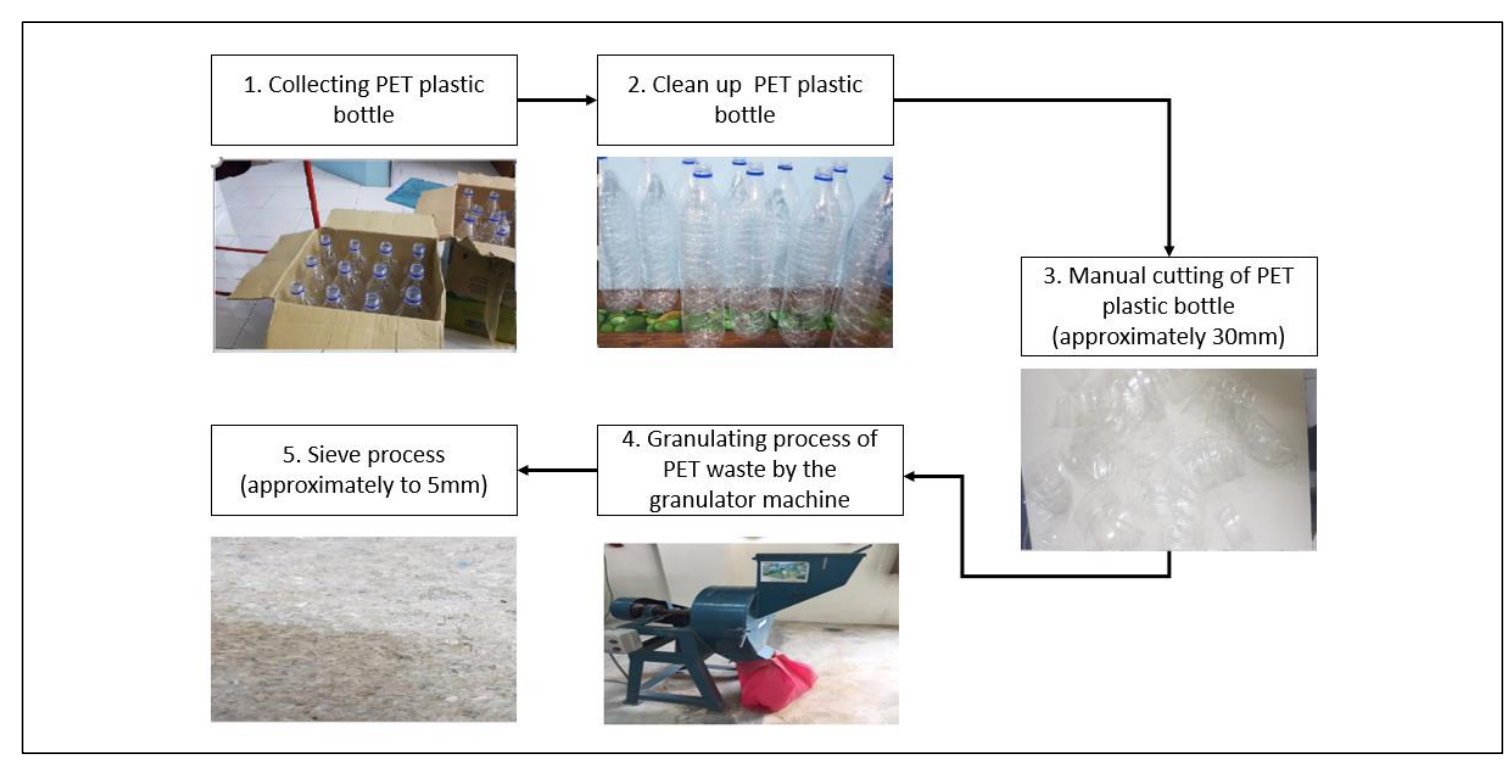

Fig. 2. The production process for granulated PET waste

\section{Table 2}

Design mix proportion of sand cement brick per sample.

\begin{tabular}{lllll}
\hline PET waste $\%$ & Cement $(\mathrm{kg})$ & Sand $(\mathrm{kg})$ & PET waste $(\mathrm{kg})$ & Water $(\mathrm{kg})$ \\
\hline Control & 0.450 & 2.250 & 0.000 & 0.270 \\
$2.5 \%$ & 0.444 & 2.222 & 0.034 & 0.266 \\
$5.0 \%$ & 0.440 & 2.194 & 0.067 & 0.264 \\
$7.5 \%$ & 0.432 & 2.161 & 0.107 & 0.259 \\
\hline
\end{tabular}

The sample was mixed, cast, and tested according to the procedure stated by BS EN 12390-2 [49] and BS EN 206 [50]. The mixing process was performed using mechanical mixing to acquire a uniform mixture. The procedure follows that the sand was first placed in the mixer, then the cement was poured into the mixer followed by the PET waste, and finally, the dry mixture was gradually added with water. The mixing continues for a few minutes to achieve the homogeneous mix. Then, the mix was placed into a steel mould. The mix was compacted with 25 strokes of a rod compacter in three layers. The samples were demoulded one day after casting at room temperature before the curing process. Next, the samples were cured for 7 and 28 days using wet blanket curing, as shown in Figure 3. The manufactured samples then underwent a series of tests, including physical, mechanical, and thermal properties

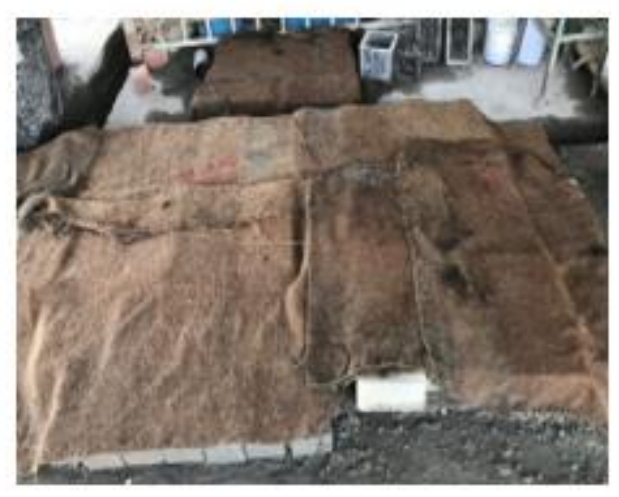

Fig. 3. Wet gunny bag curing for 7 days and 28 days 


\subsection{Laboratory Experiments}

Material testing was conducted to get the properties of the PET waste and sand characteristics used in the production of cement sand brick samples. This study involves various laboratory experiments as described in the following sub-section.

\subsubsection{Sieve analysis}

Sieve analysis was conducted to identify the particle size distribution and classify the type of sand. The test was conducted following BS 882 [51]. The sieve analysis test was carried out using a mechanical vibration machine in Geotechnical Laboratory, UTHM. The sieve size that was used in this study must be less than $5 \mathrm{~mm}$.

\subsubsection{Specific gravity}

Specific gravity is the ratio of the weight of the unit volume of sand to an equal volume of distilled water at a stated temperature. The test was conducted on PET waste and sand to determine its characteristics. A specific gravity test was conducted according to ASTM C128-15 [52].

\subsubsection{Compressive strength}

The compressive strength of bricks is the capacity of bricks to resist or withstand under compression when tested on the compressive testing machine. Compressive strength in this study can be defined as the capacity of the sample to withstand loads before failure. The test followed ASTM C67-14 [53] and was conducted at the Structural and Material Engineering Laboratory.

\subsubsection{Water absorption}

A water absorption test was carried out to measure the percentage of water absorbed by the sample. The test was followed the ASTM C67-14 [53] standard. Water absorption is an important factor due to the porous structure of the sample capable of absorbing more water through its pore inside the samples.

\subsubsection{Thermal conductivity}

This test was performed to measure the ability of the materials to conduct heat transfer, which its Kvalue presents. This test was based on the ASTMC177-19 [54] Standard test method for steady-state heat flux measurement and thermal transmission properties using the guarded-hot-plate apparatus.

\section{Results}

The results were presented in a table and graphs to assure a fuller explanation. The discussion of the result was discussed in the following sub-sections. 


\subsection{Sieve Analysis}

The sieve analysis of sand and PET waste was presented in Figure 4. The result obtained showed that the sand specimen is within the range limits of the sand particles, upper limit, and lower limit of the standard requirement. Thus, it fulfilled the required percentage for each sieve, and the distribution revealed that the sand specimen is well graded.

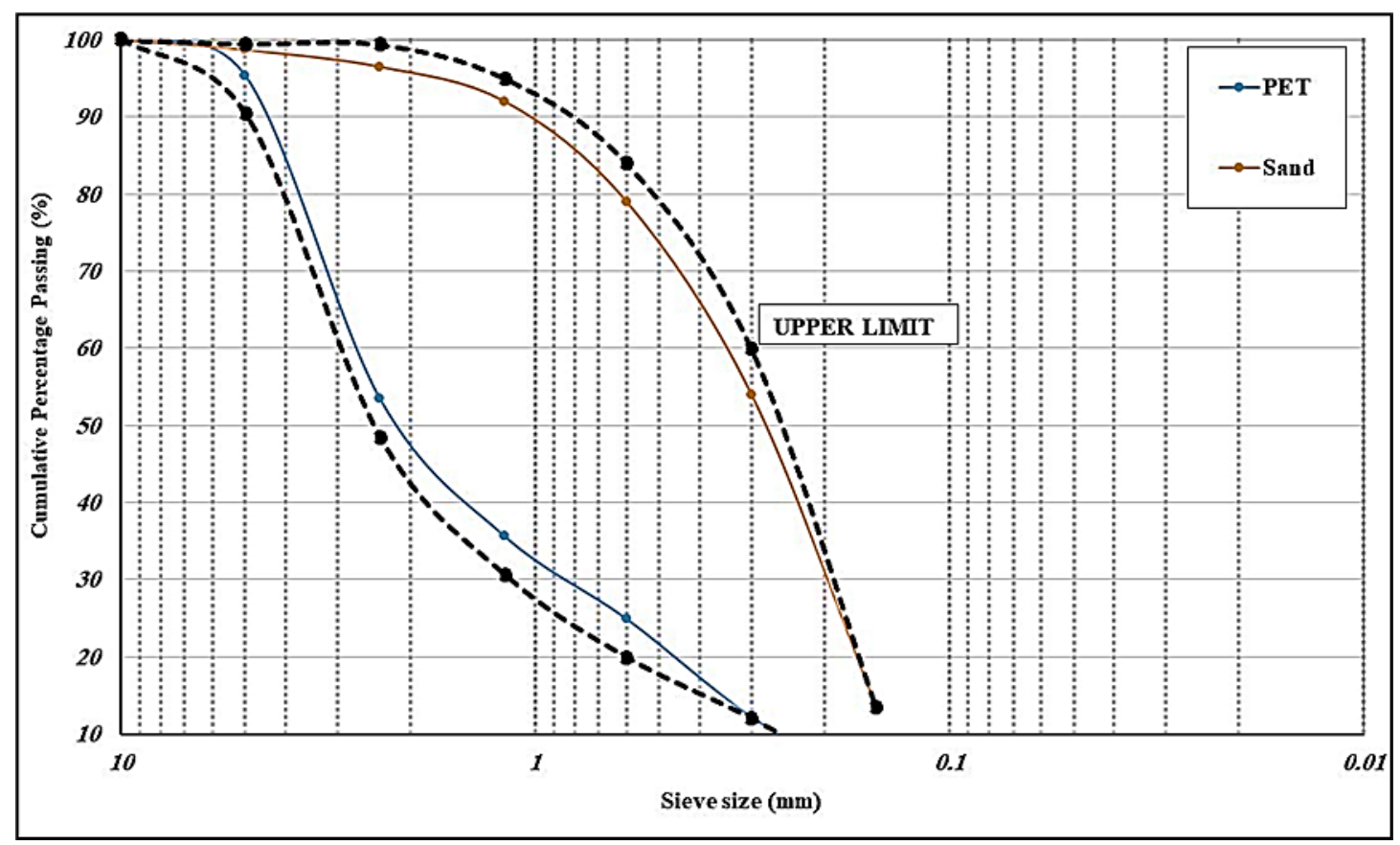

Fig. 4. Sieve analysis test for sand and PET

\subsection{Specific Gravity}

The specific gravity was performed to determine weight-volume relationships. The result of the specific gravity is shown in Table 2.

Table 2

Result of a specific gravity test

\begin{tabular}{lll}
\hline Materials & Specific gravity & Classification \\
\hline PET waste & 1.381 & Organic \\
Sand & 2.673 & Inorganic \\
\hline
\end{tabular}

Table 2 shows that the specific gravity for PET waste was lower than sand. The result obtained classifies that the sand and PET waste as inorganic and organic, respectively. The low value of the specific gravity of PET waste shows that PET waste was lighter than sand and is categorised as organic material. The results were aligned with Umasabor and Daniel [55]. The organic matter and porous particles may have specific gravity values below 2 . 


\subsection{Density}

The density result is presented in Figure 5 . The result shows that density decreased with increasing of PET waste content in the sample. Overall, all sample shows lower values of density compared to the control. The lowest density can be seen in the sample with PET $7.5 \%$, i.e., $2,093.24 \mathrm{~kg} / \mathrm{m}^{3}$. The control sample shows the highest density with $2,265.64 \mathrm{~kg} / \mathrm{m}^{3}$ at 7 days and $2,258.74 \mathrm{~kg} / \mathrm{m}^{3}$ at 28 days. It was observed that the density obtained for all the samples achieved the minimum requirements for density of normal weight, i.e., more than $2,000 \mathrm{~kg} / \mathrm{m}^{3}$ [56] for non-loadbearing brick. The density of samples containing PET waste for 7 days and 28 days decreases gradually with increased incorporation of PET waste as a partial replacement for sand. The observed reduction in density of samples is due to the replacement of heavier material (sand) with the lightweight material (crushed PET waste). PET was known as a material with a low density and lower value of specific gravity, which proved the replacement of sand with these materials contributed to the reduction in mass of the brick samples [42]. This study had the same pattern as the studies conducted by Davies and Olofinnade [57], Bijivemula and Noolu [46], and Khalid et al., [41], which revealed that the density decreases with the increase in the PET waste content in the sample composition.

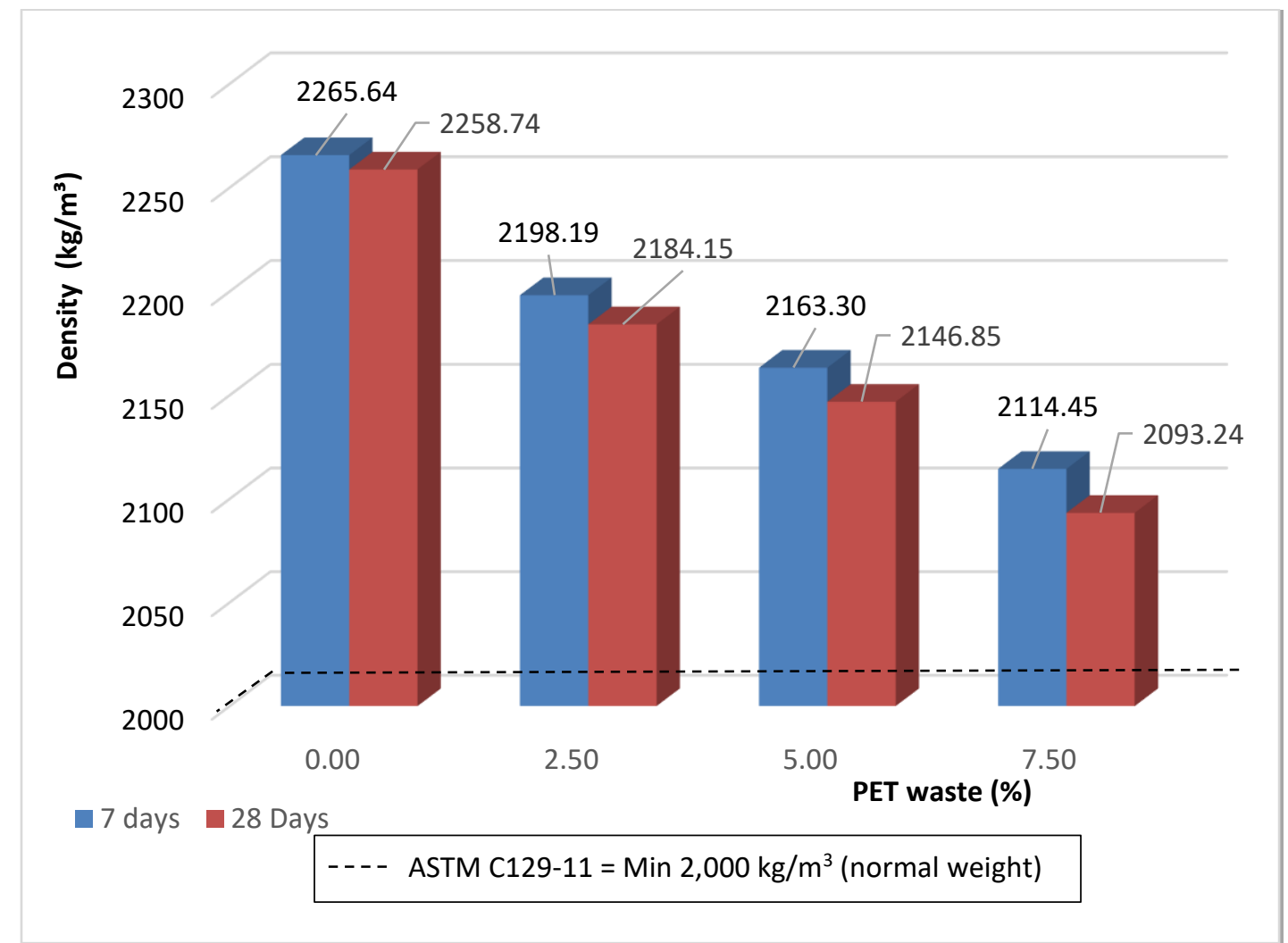

Fig. 5. The density of samples with different PET waste proportions

\subsection{Compressive Strength Test}

Compressive strength is a very important parameter that is used to meet the engineering requirement in construction applications. Based on Figure 6, the results show that the highest compressive strength of samples was $4.20 \mathrm{Mpa}$ and $5.10 \mathrm{Mpa}$ at the age of 7 and 28 days, respectively, for PET waste $2.5 \%$. Meanwhile, the lowest strength was 2.0 Mpa and 3.1 Mpa at 7 and 28 days for samples PET waste $7.5 \%$. According to ASTM C 129-11 [56], the minimum compressive strength non-load bearing masonry unit 
value is $3.45 \mathrm{MPa}$. This means that only samples with $2.5 \%$ and $5 \%$ PET waste meet the requirement at 28 days. Results show a 9.5 Mpa difference in compressive strength between control brick and 5\% PET brick at 28 days. The compressive strength of samples is decreased with the increase of PET proportion. Therefore, increasing the proportion of PET waste in the mix leads to the compressive strength decreases. Shredded plastic has a smooth surface that acts as a water repellant. Thus, it restricts the entrance of water in the voids, which is necessary for cement hydration to gain strength. The increase in the percentage of PET waste makes the bonds between cement and plastic very weak [58]. The contact becomes more irregular, resulting in a wide number of voids responsible for the deterioration of the mechanical properties [59], which, therefore, makes the deterioration of the mechanical properties [shows the compressive strength decreases. Figure 7 shows the relationship between the percentages of PET waste to the compressive strength value of brick. The relationship between the percentage (\%) of PET waste with the compressive strength of brick produces a non-linear equation $y=17.187 \mathrm{e}^{-0.466 x}$ with an $\mathrm{R}$-square $=0.8989$ is close to 1 (one), which means that the relationship between PET waste percentage significantly affects its compressive strength [60]. The increasing number of PET waste substitutions affects the compressive strength. This study corresponds to previous studies, where PET waste addition leads to a reduction of the sample's compressive strength [41], [42], [46] and [61].

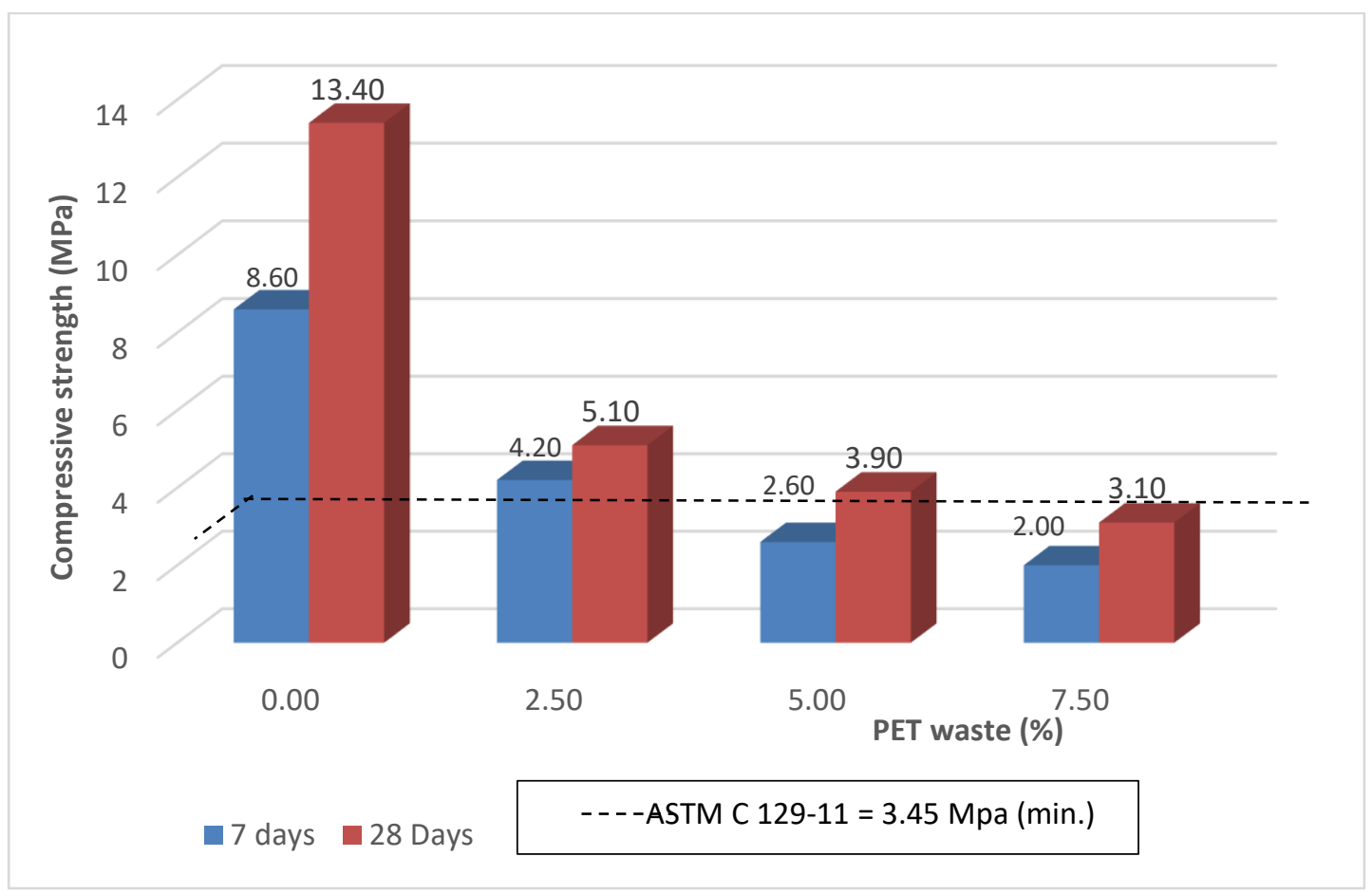

Fig. 6. The compressive strength of samples with PET waste versus Ages 


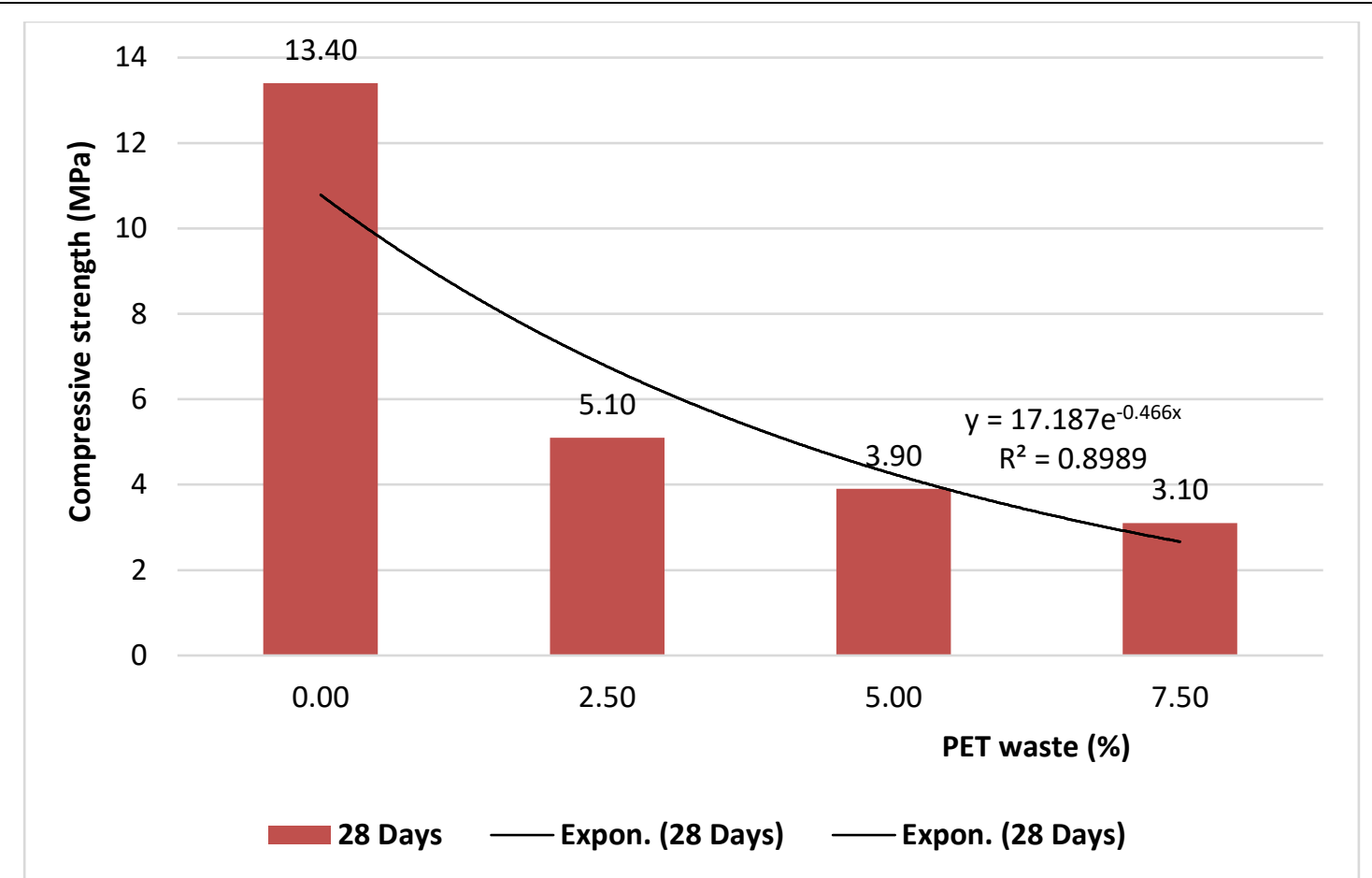

Fig. 7. Relationship of percentages of PET artificial aggregate and compressive strength of concrete

\subsection{Water Absorption Test}

The result of the water absorption test is shown in Figure 8. It can be seen that the water absorption increased as the curing time increased gradually from 7 to 28 days. The water absorption of the control sample recorded the lowest value with $211.64 \mathrm{~kg} / \mathrm{m}^{3}$ at 7 days and increased up to $226.62 \mathrm{~kg} / \mathrm{m}^{3}$ at 28 days. The minimum water absorption values for the samples containing PET waste were at $2.5 \%$ PET waste for both 7 and 28 days, with $234.12 \mathrm{~kg} / \mathrm{m}^{3}$ and $264.08 \mathrm{~kg} / \mathrm{m}^{3}$. Meanwhile, the maximum values of water absorption for the samples were at $7.5 \%$ PET waste with $273.45 \mathrm{~kg} / \mathrm{m}^{3}$ and $312.78 \mathrm{~kg} / \mathrm{m}^{3}$ at the age of 7 and 28 days. The requirements set under ASTM C55-17 [62] state that the maximum water absorption is $208 \mathrm{~kg} / \mathrm{m}^{3}, 240 \mathrm{~kg} / \mathrm{m}^{3}$, and $288 \mathrm{~kg} / \mathrm{m}^{3}$ for normal-weight brick, medium-weight brick, and lightweight brick, respectively.

Therefore, based on the requirement, most of the respective samples exceeded the requirement's limit. The increase in water absorption was due to the increase in the porosity of the bricks containing PET waste. The higher the number and the larger the pores that brick has, the greater the water absorption the brick can achieve. This finding was supported by the studies conducted by Khalid [41], where PET waste are significantly affected the increased water absorption characteristic of bricks.

Although the requirement for water absorption is not achieved (i.e., $294.05 \mathrm{~kg} / \mathrm{m}^{3}<208 \mathrm{~kg} / \mathrm{m}^{3} \mathrm{ASTM}$ C55-17) [62], this weakness can be solved by plastering both sides of the brick wall surface. Plastering is important to avoid dampness to the wall, especially during the rainy season. However, the porous brick indicated by the high-water absorption is essential to achieve thermal insulation enhancement purposes. 


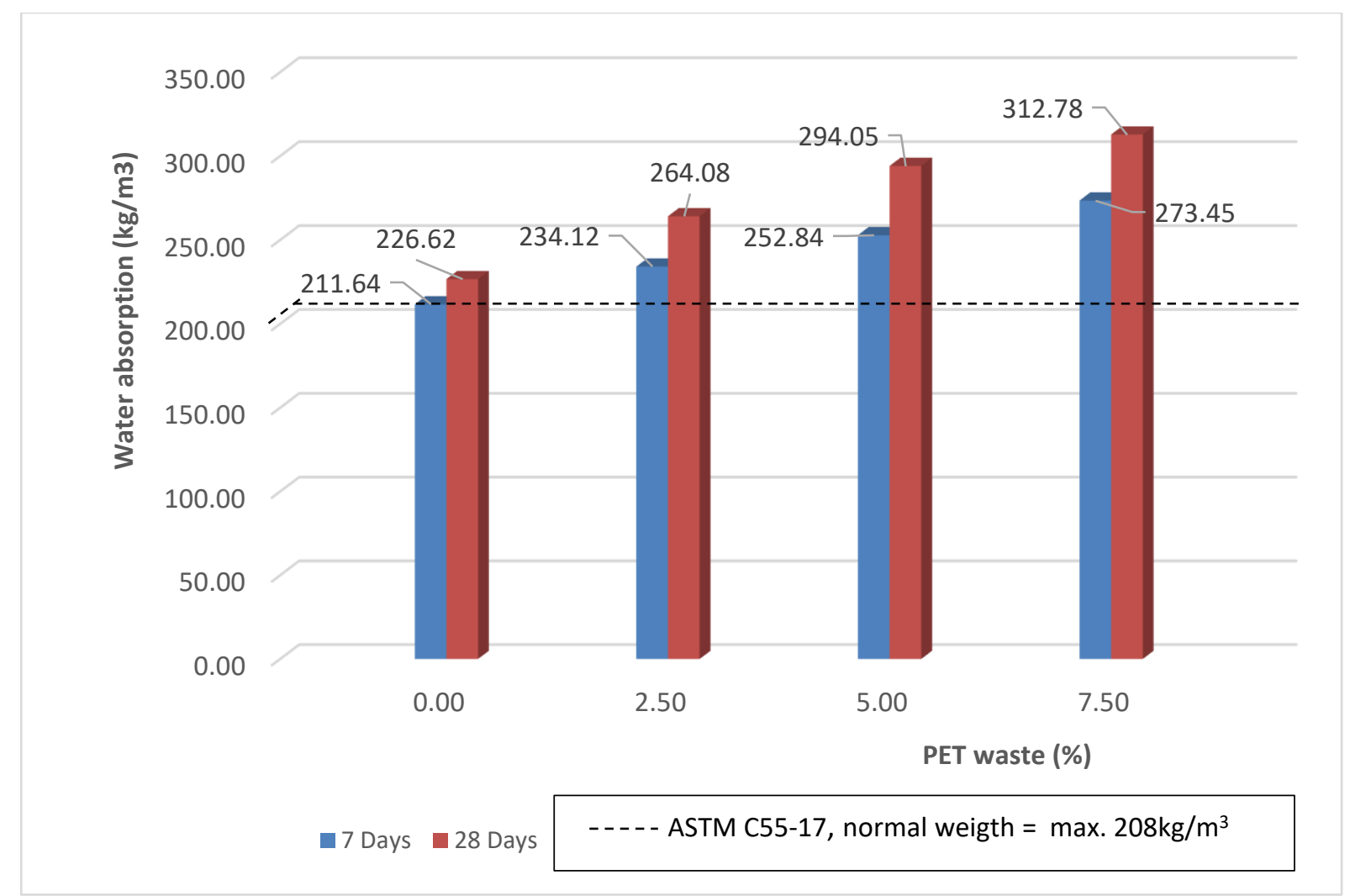

Fig. 8. The water absorption of samples with PET waste versus Ages

\subsection{Thermal Conductivity}

Figure 9 shows the thermal conductivity value of samples at the different proportions of PET waste. Based on these, it shows that the K-value was between $0.530-0.645 \mathrm{~W} / \mathrm{mK}$. The results indicate that the thermal conductivity value decreases with an increase in the proportion of waste added into the sample mixture. The addition of PET increases the number of voids in the mixture, increasing the porosity in the composite. The greater the porosity, the lower the thermal conductivity [42],[64]. According to Idris and Yusof [63], the thermal conductivity ranges from $0.51 \mathrm{~W} / \mathrm{mK}$ to $1.63 \mathrm{~W} / \mathrm{mK}$ for brick, which proved that the result met the requirement.

Marsiglio et al., [21] stated that the decrease of thermal conductivity is important to enhanced insulation capability, where the lower value for PET waste indicates that the material will conduct less heat. This finding concludes that PET waste has significant improvement in the thermal properties of cement-based materials when recycled plastics are incorporated. The ability of PET waste to improve the thermal properties of cement-based material can be attributed to the low thermal conductivity, which has been shown from the K-value obtained as indicated in Figure 9. As compared with a similar study in cement sand brick production, the result of $\mathrm{K}$-value obtained indicates that the use of PET waste in $0-5 \%$ (maximum) in the brick composition is lower $(0.581-0.725 \mathrm{~W} / \mathrm{mK}<0.714-0.744 \mathrm{~W} / \mathrm{mK})$ than the used of Metakaolin in brick [65]. Reduction of thermal conductivity is good for thermal insulation. The thermal conductivity is also dependable on the density and compressive strength, where thermal conductivity value decreases as the density and compressive strength decrease due to the effect of a higher proportion of PET waste inclusions, which has been discussed in detail in the respective section. 


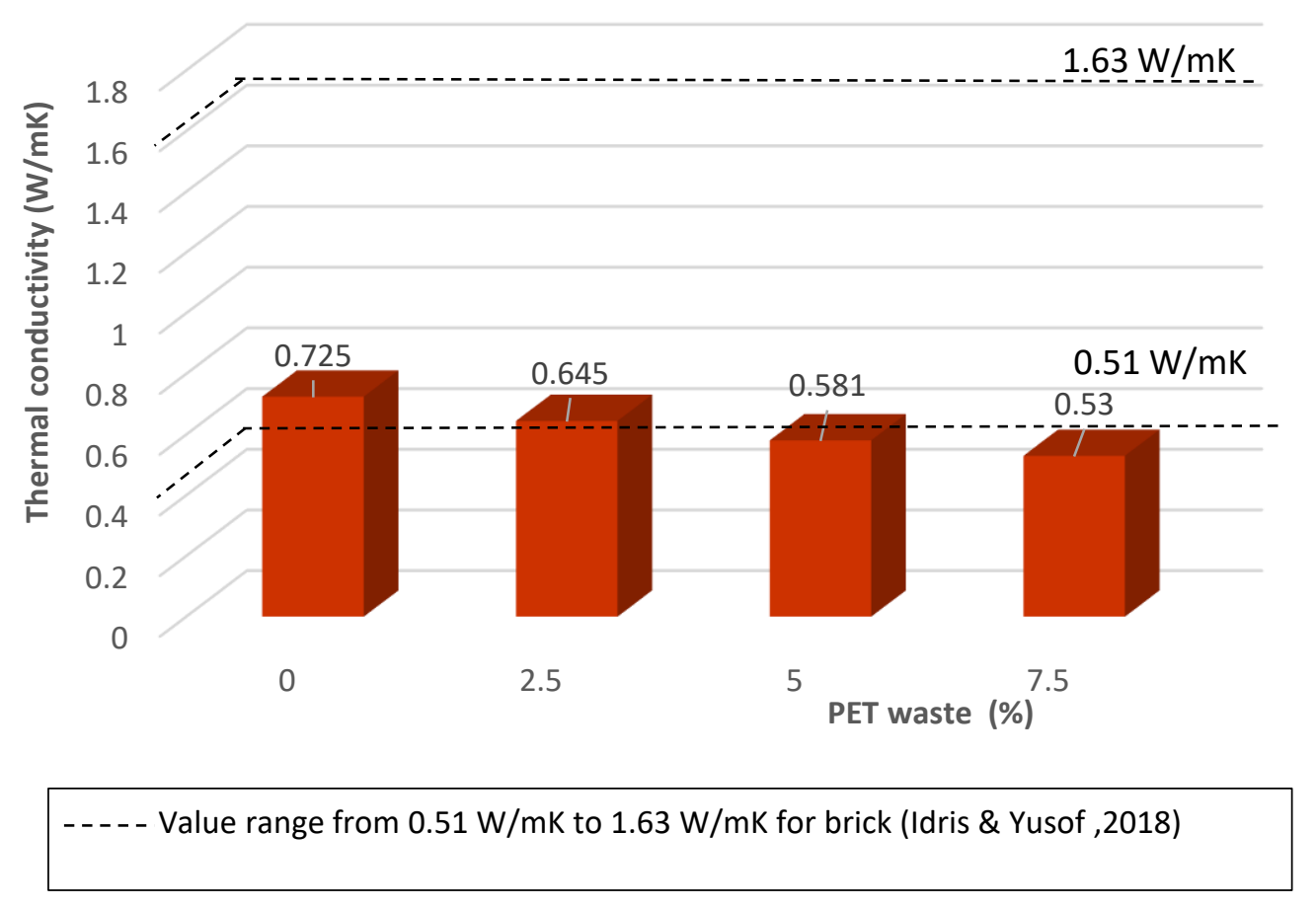

Fig. 9. The thermal conductivity of samples with PET at 28 days

\section{Conclusions}

The thermal properties of building envelope materials have a significant role in determining the thermal behaviour of buildings. Therefore, selecting a low thermal conductivity of brick walls is of considerable importance in creating low energy consumption buildings that consume less energy to maintain comfortable conditions in enclosed spaces. The following conclusions are drawn from the results of the experiment

i. The replacement of PET waste in the brick greatly affects the density of the cement sand brick. The density of the brick decreases as the percentage of replacement materials increases. In this study, all the samples are achieved the minimum requirement of normal weight $\left(2000 \mathrm{~kg} / \mathrm{m}^{3}\right)$. The greater replacement sand with the PET waste makes the brick lighter.

ii. As the percentage of PET waste increases, the compressive strength of the brick decreases. It has been observed that the substitution of $5 \%$ (maximum) of PET waste contributes to a $70.90 \%$ reduction in brick strength. The bricks have fulfilled the minimum strength requirement for nonload bearing with a limit of $5 \%$ substitution PET waste.

iii. For water absorption properties, the percentage of water absorption increases as the percentage of PET was increases. This is due to the PET waste that has led to increased porosity formation in the brick microstructure. All bricks not fulfilled the minimum requirement for water absorption, which indicates PET waste brick is porous.

iv. The utilisation of PET waste provides better thermal insulation in building walls. The thermal conductivity value of all bricks decreases with an increase in the proportion of PET waste. The low value of thermal conductivity creates low energy consumption buildings. All bricks meet the standard ranges of K-value with optimum $5 \%$ substitution PET waste considering the achievement of other important parameters (i.e., density, compressive strength, and water absorption). 
v. This study enhances the thermal conductivity of existing cement sand brick in reducing sand consumption, contributes to solving plastic waste problems, and promotes a better environmentally-friendly construction industry.

\section{Acknowledgement}

The authors would like to thank the Faculty of Civil Engineering and Built Environment, Universiti Tun Hussien Onn Malaysia, for permission and necessary research facilities. This research was not funded by any grant.

\section{References}

[1] Kaza, Silpa, Lisa Congyuan Yao, Perinaz Bhada-Tata and Frank Van Woerden. "What a Waste 2.0: A Global Snapshot of Solid Waste Management to 2050." (2018). https://doi:10.1596/978-1-4648-1329-0

[2] Watch, Market. "Malaysia-German Chamber of Commerce and Industry." (2012).

[3] Zulkernain, Nur Hanis, Paran Gani, Ng Chuck Chuan, and Turkeswari Uvarajan. "Utilisation of plastic waste as aggregate in construction materials: A review." Construction and Building Materials 296 (2021): 123669. https://doi.org/10.1016/j.conbuildmat.2021.123669.

[4] Geyer, Roland, Jenna R. Jambeck, and Kara Lavender Law. "Production, use, and fate of all plastics ever made." Science advances 3, no. 7 (2017): e1700782. https://doi.org/10.1126/sciadv.1700782

[5] Wahab, D. A., A. Abidin, and C. H. Azhari. "Recycling trends in the plastics manufacturing and recycling companies in Malaysia." Journal of Applied Sciences 7, no. 7 (2007): 1030-1035. https://doi.org/10.3923/jas.2007.1030.1035

[6] Moh, Yiing Chiee, and Latifah Abd Manaf. "Overview of household solid waste recycling policy status and challenges in Malaysia." Resources, Conservation and Recycling, 82 (2014): 50-61. https://doi.org/10.1016/i.resconrec.2013.11.004

[7] Chen, H.L., Nath, T.K., Chong, S. et al. "The plastic waste problem in Malaysia: management, recycling and disposal of local and global plastic waste." SN Appl. Sci. 3, 437 (2021). https://doi.org/10.1007/s42452-021-04234-y

[8] EPA. "Advancing sustainable materials management: facts and figures report", United States Environmental Protection Agency. (2019).

[9] Harrington, Rebecca. "By 2050, the oceans could have more plastic than fish." Business Insider(2017). https://www.businessinsider.com/plastic-in-ocean-outweighs-fish-evidence-report-2017-1.

[10] EDN. "Earth day: action Toolkit." Earth Day Network. (2018). https://www.earthday.org/wp-content/uploads/2019Earth-Day-Action-Toolkit-Final.pdf

[11] Dalberg Advisors, Wijnand de Wit, Adam Hamilton, Rafaella Scheer, Thomas Stakes, and Simon Allan. "Solving plastic pollution through accountability." WWF International, Gland. (2019). https://wwf.fi/mediabank/12129.pdf.

[12] Kershaw, P. Marine plastic debris and microplastics-Global lessons and research to inspire action and guide policy change. United Nations Environment Programme, (2016). http://hdl.handle.net/123456789/1780

[13] Krishna, R. S., J. Mishra, S. Meher, Shaswat K. Das, S. M. Mustakim, and Saurabh K. Singh. "Industrial solid waste management through sustainable green technology: Case study insights from steel and mining industry in Keonjhar, India." Materials today: proceedings 33 (2020): 5243-5249. https://doi.org/10.1016/j.matpr.2020.02.949

[14] Ruuska, Antti, and Tarja Häkkinen. "Material efficiency of building construction." Buildings 4, no. 3 (2014): $266-294$. https://doi.org/10.3390/buildings4030266

[15] Ali, Siti Birkha Mohd, M. Hasanuzzaman, N. A. Rahim, M. A. A. Mamun, and U. H. Obaidellah. "Analysis of energy consumption and potential energy savings of an institutional building in Malaysia." Alexandria Engineering Journal 60, no. 1 (2021): 805-820. https://doi.org/10.1016/i.aej.2020.10.010

[16] Mydin, Md Azree Othuman. "Effective thermal conductivity of foamcrete of different densities." Concr. Res. Lett 2, no. 1 (2011). https://doi.org/81-189.10.20528/cjcrl

[17] Wonorahardjo, Surjamanto, Inge Magdalena Sutjahja, Y. Mardiyati, Heri Andoni, Dixon Thomas, Rizky Amalia Achsani, and S. Steven. "Characterising thermal behaviour of buildings and its effect on urban heat island in tropical areas." International Journal of Energy and Environmental Engineering 11, no. 1 (2020): 129-142. https://doi.org/10.1007/s40095-019-00317-0

[18] Zhou, Ao, Kwun-Wah Wong, and Denvid Lau. "Thermal insulating concrete wall panel design for sustainable built environment." The Scientific world journal 2014 (2014). I https://doi.org/10.1155/2014/279592

[19] Asdrubali, Francesco, Francesco D'Alessandro, and Samuele Schiavoni. "A review of unconventional sustainable building insulation materials." Sustainable Materials and Technologies $4 \quad$ (2015): $1-17$. https://doi.org/10.1016/i.susmat.2015.05.002 
[20] Intini, Francesca, and Silvana Kühtz. "Recycling in buildings: an LCA case study of a thermal insulation panel made of polyester fiber, recycled from post-consumer PET bottles." The international journal of life cycle assessment 16, no. 4 (2011): 306-315. https://doi.org/10.1007/s11367-011-0267-9

[21] Marsiglio, Laura, Susan Cheng, Elizabeth Falk, Andrew Fugh, Kelly Mulvaney, Brian Slocum, Donald Morris, Ganesh Balasubramanian, and Khanjan Mehta. "Comparing the Properties of Polyethylene Terephthalate (PET) Plastic Bricks to Conventional Concrete Masonry Units." In 2020 IEEE Global Humanitarian Technology Conference (GHTC), pp. 1-6. IEEE, (2020). https://doi.org/10.1109/GHTC46280.2020.9342915.

[22] Ismail, Zainab Z., and Enas A. Al-Hashmi. "Use of waste plastic in concrete mixture as aggregate replacement." Waste management 28, no. 11 (2008): 2041-2047. https://doi.org/10.1016/i.wasman.2007.08.023

[23] Thakur, Gitanjali, Mohamad Asalam, and Mohammed El Ganaoui. "Energy efficient building envelope using waste PET in concrete." In MATEC Web of Conferences, vol. 307, p. 01022. EDP Sciences, (2020). https://doi.org/10.1051/matecconf/202030701022

[24] GESB. "A Study on Plastic Management in Peninsular Malaysia." National solid waste management Department Ministry of Housing and Local Government Malaysian, Report, Selangor, December, 1-266, (2011). http://ipspn.kpkt.gov.my/resources/index/user 1/Sumber Rujukan/kajian/JPSPN\%20Plastic\%20Study\%20\%20Final\%20Report\%20GESB\%20-\%20Softcopy\%20English\%20Ed2.pdf.

[25] Abas, N.F., and Omosebi, T.O. "Utilization of PET wastes aggregate in building construction - a review." International Journal of Recent Technology and Engineering 9, no. 3 (2020): 656-663. https://doi.org/10.35940/ijrte.C4636.099320

[26] Badave, N., and Pise, D. "Study on the effect of waste Polyethylene Terephthalate bottle fibers on silica fume concrete - A review." International Journal of Scientific \& Engineering Research 9, no. 2 (2018): 2046-2049.

[27] Haque, Md Sazzadul. "Sustainable use of plastic brick from waste PET plastic bottle as building block in Rohingya refugee camp: a review." Environmental Science and Pollution Research 26, no. 36 (2019): 36163-36183. https://doi.org/10.1007/s11356-019-06843-y

[28] Frigione, Mariaenrica. "Recycling of PET bottles as fine aggregate in concrete." Waste management 30, no. 6 (2010): 1101-1106. https://doi.org/10.1016/i.wasman.2010.01.030

[29] ASTM C129-17, Standard Specification for Nonloadbearing Concrete Masonry Units, ASTM International, West Conshohocken, PA, (2017). https://doi.org/10.1520/C0129-17

[30] Kamar, Kamarul Anuar Mohamad, Zuhairi Abd Hamid, Mohd Khairolden Ghani, Charles Egbu, and Mohammed Arif. "Collaboration initiative on green construction and sustainability through Industrialized Buildings Systems (IBS) in the Malaysian construction industry." International Journal of Sustainable Construction Engineering and Technology 1 , no. 1 (2010): 119-127. https://publisher.uthm.edu.my/ojs/index.php/IJSCET/article/view/56.

[31] Kibwami, Nathan, and Apollo Tutesigensi. "Enhancing sustainable construction in the building sector in Uganda." Habitat international 57 (2016): 64-73. https://doi.org/10.1016/j.habitatint.2016.06.011

[32] Mohd Yassin, Nurain Izzati, Suraya Hani Adnan, Shahiron Shahidan, Mohamad Hairi Osman, Mohamad Luthfi Ahmad Jeni, Wan Amizah Wan Jusoh, Zalipah Jamellodin, Noor Azlina Abdul Hamid, and Faridahanim Ahmad. "Concrete Brick Properties Incorporating EPS and POFA As Replacement Materials." Journal of Advanced Research in Materials Science 77, no. 1 (2021): 14-25. https://doi.org/10.37934/arms.77.1.1425.

[33] Shakir, Alaa A., and Ali Ahmed Mohammed. "Manufacturing of Bricks in the Past, in the Present and in the Future: A state of the Art Review." International Journal of Advances in Applied Sciences (IJAAS) 2, no. 3 (2013): 145-156. https://doi.org/10.11591/IJAAS.V2I3.1751

[34] Azmi, N. B., F. S. Khalid, J. M. Irwan, P. N. Mazenan, Z. Zahir, and S. Shahidan. "Performance of composite sand cement brick containing recycle concrete aggregate and waste polyethylene terephthalate with different mix design ratio." In IOP Conference Series: Earth and Environmental Science, vol. 140, no. 1, p. 012129. IOP Publishing, (2018). https://doi.org/10.1088/1755-1315/140/1/012129

[35] Gavriletea, Marius Dan. "Environmental impacts of sand exploitation. Analysis of sand market." Sustainability 9 , no. 7 (2017): 1118. https://doi.org/10.3390/su9071118

[36] Bhairappanavar, Shruti, Rui Liu, and Abdul Shakoor. "Eco-friendly dredged material-cement bricks." Construction and Building Materials 271 (2021): 121524. https://doi.org/10.1016/j.conbuildmat.2020.121524

[37] Akinyele, J. O., and I. O. Toriola. "The effect of crushed plastics waste on the structural properties of sandcrete blocks." African Journal of Science, Technology, Innovation and Development 10, no. 6 (2018): 709-713. https://doi.org/10.1080/20421338.2018.1496614

[38] T. Ochi, S. Okubo, K. Fukui. "Development of recycled PET fiber and its application as concrete-reinforcing fiber." Cement and Concrete Composites 29, no. 6 (2007): 448-455. https://doi.org/10.1016/i.cemconcomp.2007.02.002

[39] Amir Mahyar Azhdarpour, Mohammad Reza Nikoudel, and Milad Taheri. "The effect of using polyethylene terephthalate particles on physical and strength-related properties of concrete; a laboratory evaluation." Construction and Building Materials 109 (2016): 55-62. https://doi.org/10.1016/j.conbuildmat.2016.01.056 
[40] Das, S., M. T. Alam, and I. Chowdhury. "Utilisation of plastic Waste In Concrete as Partial Replacement of Fine Aggregate." In Proceedings of 3rd International Conference on Advances in Civil Engineering. Chittagog. Bangladesh. (2016).

[41] Khalid, Faisal Sheikh, Nurul Bazilah Azmi, Puteri Natasya Mazenan, Shahiron Shahidan, and Noorwirdawati Ali. "The mechanical properties of brick containing recycled concrete aggregate and polyethylene terephthalate waste as sand replacement." InE3S Web of Conferences, vol. 34, p. $01001 . \quad$ EDP Sciences, (2018). https://doi.org/10.1051/e3sconf/20183401001

[42] Barreto, José Maurício Lima et al. "Analysis of the physical and mechanical properties of pressed concrete blocks without structural function with recycled PET incorporation." Material (Rio J.) 24, no. 2 (2019): e12357. https://doi.org/10.1590/S1517-707620190002.0672

[43] Limami, Houssame, Imad Manssouri, Khalid Cherkaoui, and Asmae Khaldoun. "Study of the suitability of unfired clay bricks with polymeric HDPE \& PET wastes additives as a construction material." Journal of Building Engineering 27 (2020): 100956. https://doi.org/10.1016/i.jobe.2019.100956

[44] Akinyele, J. O., U. T. Igba, and B. G. Adigun. "Effect of waste PET on the structural properties of burnt bricks." Scientific African 7 (2020): e00301. https://doi.org/10.1016/i.sciaf.2020.e00301

[45] Awoyera, Paul O., Oladimeji B. Olalusi, and Samuel Ibia. "Water absorption, strength and microscale properties of interlocking concrete blocks made with plastic fibre and ceramic aggregates." Case Studies in Construction Materials 15 (2021): e00677. https://doi.org/10.1016/j.cscm.2021.e00677.

[46] Bijivemula, Sudheer Kumar Reddy, and Venkatesh Noolu. "Analysis of mechanical and durability properties of alkali activated blocks using PET flakes and Fly-ash." Materials Today: Proceedings 43 (2021): $1093-1097$. https://doi.org/10.1016/i.matpr.2020.08.326

[47] MS 522 Part 12003 Portland Cement (Ordinary and Rapid-hardening) Part 1 Specification (Second Revision)-709539, Department of Standards Malaysia, (2003).

[48] MS 28 Methods of test for water for making concrete, Department of Standard Malaysia, (1985).

[49] BS EN 12390-2. Testing hardened concrete-Part 2: Making and curing specimens for strength, British Standards Institution, (2009).

[50] BS EN 206. Concrete-specification, performance, production and conformity, British Standards Institution, London, (2013)

[51] BS 882. Specification for aggregates from natural sources for concrete. British Standards Institution, London. (1992).

[52] ASTM C128 - 15 Standard Test Method for Relative Density (Specific Gravity) and Absorption of Fine Aggregate, ASTM International, West Conshohocken, PA, (2015). https://doi.org/10.1520/C0128-15

[53] ASTM C67-14, Standard Test Methods for Sampling and Testing Brick and Structural Clay Tile, ASTM International, West Conshohocken, PA, (2014). https://doi.org/10.1520/C0067-14

[54] ASTM C177-19, Standard Test Method for Steady-State Heat Flux Measurements and Thermal Transmission Properties by Means of the Guarded-Hot-Plate Apparatus, ASTM International, West Conshohocken, PA, (2019). https://doi.org/10.1520/C0177-19

[55] Umasabor, Richie I., and Samuel C. Daniel. "The effect of using polyethylene terephthalate as an additive on the flexural and compressive strength of concrete." Heliyon 6, no. 8 (2020): e04700. https://doi.org/10.1016/j.heliyon.2020.e04700

[56] ASTM C129-11, Standard Specification for Nonloadbearing Concrete Masonry Units, ASTM International, West Conshohocken, PA, (2011). https://doi.org/10.1520/C0129-11

[57] Davies, I. E. E., and O. M. Olofinnade. "Suitability of using post-consumer polyethylene terephthalate wastes in cementbased hollow sandcrete blocks." In IOP Conference Series: Materials Science and Engineering, vol. 1036, no. 1, p. 012046. IOP Publishing, 2021. https://doi.org/10.1088/1757-899X/1036/1/012046

[58] Thorneycroft, James, John Orr, Purnanand Savoikar, and R. J. Ball. "Performance of structural concrete with recycled plastic waste as a partial replacement for sand." Construction and Building Materials 161 (2018): 63-69. https://doi.org/10.1016/i.conbuildmat.2017.11.127

[59] Pezzi, L., Pier Antonio De Luca, D. Vuono, F. Chiappetta, and Alfonso Nastro. "Concrete products with waste's plastic material (bottle, glass, plate)." In Materials Science Forum, vol. 514, p. 1753. Trans Tech Publications Ltd, 2006. https://doi.org/10.4028/www.scientific.net/MSF.514-516.1753

[60] Rahman, Muhammad Junaedy, Arman Setiawan, and Muhammad Ihsan. "Examining Polyethylene Terephthalate (PET) as Artificial Coarse Aggregates in Concrete." Executive Manager 6, no. 12 (2020): 2416. https://doi.org/10.28991/cej2020-03091617

[61] Awoyera, P. O., and Adeyemi Adesina. "Plastic wastes to construction products: Status, limitations and future perspective." Case Studies in Construction Materials 12 (2020): e00330. https://doi.org/10.1016/i.cscm.2020.e00330

[62] ASTM C55-17, Standard Specification for Concrete Building Brick, ASTM International, West Conshohocken, PA, (2017). https://doi.org/10.1520/C0055-17 
[63] Idris, Irham Hameeda Mohamad, and Nur Zulaikha Yusof. "Development of low thermal mass cement-sand block utilising peat soil and effective microorganism." Case studies in construction materials 8 (2018): 8-15. https://doi.org/10.1016/j.cscm.2017.11.004

[64] Saman, Nor Sarwani Mat, Rafikullah Deraman, and Mohamad Hazmi Hamzah. "Development of low thermal conductivity brick using rice husk, corn cob and waste tea in clay brick manufacturing." In AIP Conference Proceedings, vol. 1901, no. 1, p. 130007. AIP Publishing LLC, 2017. https://doi.org/10.1063/1.5010567

[66] Deraman, Rafikullah, Rabiatul Syahindah Mustaffa, Mohd Hanif Ismail, Muhammad Fikri Hasmori, and Sasitharan Nagapan. "The Effect of Metakaolin in Production of Low Thermal Conductivity Cement Sand Brick." Sustainable Waste Utilisation in Bricks, Concrete, and Cementitious Materials: Characteristics, Properties, Performance, and Applications 129 (2021): 265. https://doi.org/10.1007/978-981-33-4918-6-14 